\title{
First report of cucumber mosaic virus infecting pear in Korea
}

\author{
Hyo-Jeong Lee ${ }^{1} \cdot$ Nam-Yeon Kim ${ }^{1} \cdot$ Rae-Dong Jeong ${ }^{1}$ \\ Received: 29 April 2018 / Accepted: 15 May 2018 / Published online: 24 May 2018 \\ (C) Società Italiana di Patologia Vegetale (S.I.Pa.V.) 2018
}

\begin{abstract}
A survey for pear viruses was conducted during 2017 in Namyangju, Naju, Chonan, Sangju, and Ulsan provinces, which are important fruit-growing areas in Korea. Pear trees with typical mosaic viral symptoms were observed in Namyangju and Sangju provinces. In total, 10 leaf samples with mosaic symptoms and 10 symptomless samples were collected and tested for viruses. Apple mosaic virus (ApMV), which is the only virus reported as showing mosaic symptoms on infected pears in Korea, was not detected by RTPCR (Cho et al. 2015). Recently, a study reported that cucumber mosaic virus (CMV) was infecting apple trees in China (Hu et al. 2016). Based on the symptoms and this previous study, CMV infection was suspected. Samples were selected and the presence of CMV was confirmed by RT-PCR using Cucumovirus genus-specific primers designed from a highly conserved region of the coat protein $(\mathrm{CP})$ gene $\left(5^{\prime}-\right.$ TGGTCGTCCAACTATTAACCAC $-3^{\prime}$ and 5'- TACTGATA AACCAGTACCGGTGA -3') (Choi et al. 1999). DNA fragments of the expected size ( $321 \mathrm{bp}$ ) were amplified, cloned, and sequenced. BLAST analysis of a CMV sequence (LC375157) showed 99\% identity with the CP gene of several CMV isolates of Rudbeckia hirta (GU327365), Capsicum annuum (KC527751), Nicotiana benthamiana (AB369273), Cucumis sativus (KT270569), and Cucumis melo
\end{abstract}

(KT270566). Furthermore, phylogenetic analysis indicated that the virus isolate named CMV-Pns belongs to the CMV group IB. CMV-Pns caused weak systemic mosaic symptoms on Nicotiana glutinosa and $N$. rustica at 10 to 14 days post inoculation. To our knowledge, this is the first report of CMV infection in pear trees in Korea.

Funding This study was funded by Korea Institute of Planning and Evaluation for Technology in Food, Agriculture, Forestry and Fisheries (IPET) through (Agri-Bioindustry Technology Development Program), funded by Ministry of Agriculture, Food and Rural Affairs (MAFRA) (No. 317006-04-2-HD030).

\section{References}

Cho I-S, Choi G-S, Kwon S-J (2015) Molecular diagnostic assay for the simultaneous detection of pome fruit viruses. International Journal of Applied Sciences and Technology 5:39-46

Choi S-K, Choi J-K, Park W-M, Ryu K-H (1999) RT-PCR detection and identification of three species of cucumoviruses with a genusspecific single pair of primers. $J$ Virol Methods 83:67-73

$\mathrm{Hu}$ Y, Shi HW, Jing CC, Li K, Sun XC, Wu GT, Zhou CY, Qing L (2016) First report of cucumber mosaic virus infecting apple in China. J Plant Pathol 98:181-181
Rae-Dong Jeong jraed2@jnu.ac.kr

1 Department of Applied Biology, Institute of Environmentally Friendly Agriculture, Chonnam National University, Gwangju 61185, South Korea 